\title{
Pendampingan Membangun Portal Aplikasi Android Gamelan Wirun untuk Memperluas Pasar Gamelan
}

\author{
Yohan Wismantoro $^{1}$, Karis Widiatmoko ${ }^{2}$ \\ ${ }^{1,2,}$ Universitas Dian Nuswantoro Semarang \\ E-mail: 1'yohan.wismantoro@dsn.dinus.ac.id, ${ }^{2}$ karis@dsn.dinus.ac.id
}

\begin{abstract}
Abstrak
Ekonomi kreatif merupakan bagian yang integral dan semakin strategis dalam perencanaan pembangunan nasional guna meningkatkan kesejahteraan masyarakat. Gamelan, merupakan salah satu warisan budaya bangsa serta kemanusiaan yang potensial untuk dikembangkan dalam rangka pengembangan industri kreatif, peningkatan kesejahteraan masyarakat serta penanaman nilai-nilai luhur budaya bangsa. Secara empiris, kontribusi industri kreatif terhadap pembangunan adalah signifikan. Pembuatan aplikasi android Gamelan Wirun dibuat untuk strategi penetrasi pasar dan perluasan pasar, yaitu meningkatkan penjualan gamelan melalui teknologi. Aplikasi ini dapat diakses melalui play store android di smartphone. Dengan demikian pasar menjadi langsung, artinya pembeli gemelan dimanapun baik lokal, nasional maupun di seluruh dunia dapat langsung berinteraksi melalui program Aplikasi Gamelan Wirun. Melalui pendampingan dan pelatihan, pemahaman dan awareness pengrajin terhadap penggunaan teknologi untuk transaksi menjadi semakin tinggi.
\end{abstract}

Kata kunci: Gamelan Wirun, Play Store, industri kreatif

\begin{abstract}
The creative economy is an integral and increasingly strategic part of national development planning to improve community welfare. Gamelan is one of the nation's cultural heritage and humanity that can be developed in developing creative industries, improving people's interest, and instilling the noble values of the nation's culture. Empirically, the contribution of the creative industry is significant. The Gamelan Wirun android application development was made for a market penetration strategy and market expansion, namely increasing gamelan sales through technology. This application can be accessed via the android play store on a smartphone. Thus, the market becomes direct, meaning that buyers who are happy anywhere, whether locally, nationally, or worldwide, can directly interact through the Gamelan Wirun application program. Through mentoring and training, the craftsmen's understanding and awareness of the use of technology for transactions is getting higher.
\end{abstract}

Keyword: Gamelan Wirun, Play Store, Creative Industry

\section{PENDAHULUAN}

Ekonomi kreatif merupakan bagian yang integral dan semakin strategis dalam perencanaan pembangunan nasional guna meningkatkan kesejahteraan masyarakat. Secara empiris, kontribusi industri kreatif terhadap pembangunan selama tahun 2002-2006 diketahui sebesar 6,3 persen tarhadap PDB, penyerapan tenaga kerja sebesar 5,79 persen, kontribusi ekspor sebesar 10,58 persen serta memiliki sumbangan terhadap total perusahaan sebesar 6,15 persen. Pada tahun 2015-2019, ekonomi kreatif ditargetkan memiliki kontribusi terhadap PDB sebesar 7-7,5 persen (dengan Industri Kreatif minimal 5-6 persen), menyerap tenaga kerja sebesar 10,5 -11 persen, dan menyumbang devisa sebesar 6,5 - 8 persen (www.kemenpar.go.id). [1] Transformasi ekonomi yang didukung perkembangan teknologi informasi saat ini, ekonomi pertanian-ekonomi industri- ekonomi informasi - ekonomi kreatif semakin memberikan peluang industri kreatif utnuk berkembang. 
Gamelan, merupakan salah satu warisan budaya bangsa serta kemanusiaan yang potensial untuk dikembangkan dalam rangka pengembangan industri kreatif, peningkatan kesejahteraan masyarakat serta penanaman nilai-nilai luhur budaya bangsa. Sebagaimana diketahui bahwa perkembangan musik-musik di Barat sekarang ini banyak yang berpaling ke Wilayah Timur, termasuk seni gamelan yang dimiliki oleh bangsa Indonesia. Bahkan seni gamelan berkembang pesat di Vancouver Kanada melalui kelompok-kelompok peminat jenis seni. Di Vancouver juga terdapat dua universitas besar yang secara aktif mendukung perkembangan seni gamelan. "The School for the Contemporary Arts" di "Simon Fraser University" sudah sejak 1990 menawarkan program kelas gamelan setiap musim semi dan panas (http://www.kapanlagi.com, Sabtu, 07 April 2014; 21:21). [2]. Fenomena ini menjadi pijakan optimis bahwa industri kreatif Gamelan Jawa, merupakan salah satu asset industri kreatif musik yang sangat potensial. Jika Apresiasi gamelan di manca negara semakin meningkat maka akan berdampak naiknya jumlah permintaan perangkat gamelan.

Beberapa penelitian dan literatur pada inovasi dan kewirausahaan di bidang pendidikan (Chikweche, 2017 [3]; Haugh dan Pardy, 1999 [4]; Merlo dan Auh, 2009 [5]) kebanyakan berfokus pada ide-ide bagaimana proses eksternal dan teknik-teknik dapat diterapkan untuk sistem pendidikan untuk meningkatkan kinerja pendidikan. Penelitian tentang gamelan, dengan demikian dapat diarahkan untuk membahas cara-cara menyangkut ide-ide internal, proses, dan teknik yang menyangkut sistem pendidikan, sekolah terutama inovasi dan kewirausahaan untuk generasi muda di seluruh dunia. Perhatian khusus ini memberikan kepada generasi muda untuk siap berpartisipasi dalam ekonomi pengetahuan (knowledge economy) dengan menjadi inovator informasi dan knowledge entrepreneurs. Namun demikian, saat ini masih terdapat sejumlah kendala terkait seni gamelan. Selain minat generasi muda serta pengetahuan generasi muda terhadap gamelan relatif rendah, alat musik gamelan dan beragam dan bervolume menyebabkan pemanfaatannya kurang praktis. Sistem penjualan gamelan masih cenderung menggunakan model tradisional sehingga menghambat pemenuhan permintaan. Pemanfaatan teknologi informasi (TI) diharapkan memberikan kemudahan penyebaran musik gamelan. [6] [7]

Seperti industri kreatif lainnya, pengembangan musik gamelan dihadapkan pada sejumlah tantangan, salah satu diantaranya adalah kesiapan SDM. Bertitik tolak dari kondisi tersebut, selain penguatan SDM industri kreatif gamelan, pengembangan Portal Aplikasi Android sangat diperlukan untuk memperluas pasar.

Seperti telah disinggung dalam uraian terdahulu, sedikitnya pemesanan terhadap gamelan tidak saja karena harga gamelan yang tinggi tetapi juga karena gamelan merupakan seni budaya yang kurang populer saat ini. Dalam berbagai macam perhelatan, solo organ, dan grup band lebih banyak digunakan. Selain lebih praktis terkait dengan peralatan dan mobilisasi peralatan musiknya, musikmusik populer saat ini lebih membumi dibanding gamelan. Oleh karena itu, bagaimana membuat gamelan dapat diterima sebagaimana musik- musik populer adalah sebuah tantangan besar terhadap industri gamelan. Gamelan adalah musik warisan budaya bangsa yang perlu dilestarikan. Selain mempertahankan warisan budaya bangsa, dengan mempopulerkan musik gamelan secara tidak langsung ak an menghidupkan/mengembangakan industri gamelan yang pada akhirnya akan berdampak pada peningkatan kesejahteraan pelaku usaha industri gamelan dan masyarakat pada umumnya.

Pemanfaatan teknologi informasi dapat menjadi sarana untuk mempopulerkan sekaligus mengembangkan usaha pada indutri gamelan. Dengan memanfaatkan teknologi informasi, musik gamelan maupun hasil-hasil dari industri kreatif gamelan akan menjadi lebih mudah diakses oleh masyarakat sehingga musik gamelan bukan menjadi sesuatu yang "asing" bagi masyarakat terutama generasi muda. Dengan pendekatan awareness, interest, evaluation, trial, dan adoption, paparan berikut memaparkan tingkat adopsi teknologi informasi oleh para pelaku usaha pada industri kreatif gamelan untuk memperluas pasar gamelan. Beberapa variabel adopsi teknologi informasi yang digunakan umum dilakukan adalah dengan menggunakan :

a. Berbagai informasi terkait dengan Pemasaran online

b. Menjual dengan media facebook

c. Menjual dengan media intagram 


\section{d. Menjual dengan media Whatsapp (WA) \\ e. Mengembangkan portal/website}

Mengacu pada beberapa variabel adopsi tersebut, sebagian dari narasumber mengatakan tidak memanfaatkan satupun karena cenderung tidak aware terhadap pemanfaatan teknologi informasi. Sementara itu, sebagian yang lain sudah aware namun mengatakan bahwa mereka bahwa informasi terkait dengan pemanfaatan teknologi informasi untuk pengembangan usaha hanya sedikit. Mengenai ketertarikan, untuk menggunakan teknologi informasi, hanya terdapat satu narasumber yang menyatakan sedang mengumpulkan informasi lebih banyak mengenai teknologi informasi untuk pengembangan usaha dan terdapat satu narasuber yang sudah mengadopsi teknologi informasi dengan mengembangkan website. Dengan melihat gambaran tersebut dapat diatakan bahwa saat ini adopsi teknologi informasi pada industri kreatif gamelan sangat rendah.

Penelusuran lebih lanjut mengenai rencana untuk memanfaatkan teknologi informasi pada masa yang akan datang, semua narasumber menyatakan tertarik untuk mengadopsi teknologi informasi. Mereka berharap adanya pelatihan pemanfaatan teknologi informasi untuk pengembangan usaha, khususnya melalui pengembangan portal gamelan.

Berdasarkan latar belakang yang telah diuraikan diatas maka rumusan masalah untuk kegiatan pengabdian ini yaitu: bagaimana pelaksanaan pendampingan membangun Aplikasi Android untuk memperluas pasar. Adapun tujuan pengabdian ini dilaksanakan yakni membangun aplikasi android yang dapat digunakan secara mudah di smarphone untuk melakukan transaksi pembelian gamelan.

\section{METODE PENELITIAN}

Tahapan kegiatan dalam pelatihan, dan pendampingan Aplikasi Gamelan Wiru adalah sebagai berikut:

1. Analisis masalah dan solusi: pada tahap ini, permasalahan dan kebutuhan dari pengguna dianaliasis untuk mengetahui tingkat kebutuhan informasi yang akan digunakan untuk aplikasi android, yaitu pada tingkat Admin, Seller dan Customer

2. Pelatihan dan pedampingan: pada tahap ini, mitra diberikan pelatihan dalam mengoperasikan Aplikasi Gamelan Wirun melalui perangkat smartphone untuk meningkatkan efektifitas penjualan gamelan baik gamelan secara item maupun seperangkat gamelan lengkap.

Umpan balik: umpan balik dilakukan pada akhir tahapan. Hal ini dimaksudkan untuk mengidentifikasi jika masih terdapat kekurangan dan kelemahan pengguna dalam menggunakan Aplikasi Android Gamelan Wirun

\subsection{Analisis Masalah dan Solusi}

Masalah yang dihadapi Pengrajin Gamelan Wirun dianalisis dengan membentuk Focus group discussion (FGD), sehingga dapat diketahui efektifitas Aplikasi Android dalam meningkatkan penjualan gamelan. Pengrajin Gemelan di daerah Wirun dilatih bagaimana cara mengupdate data dari perangkat smartphone. Ditingkat Seller dilatih bagaimana cara memasukkan foto, mengisi nama, email, nomer telpon, Nama Toko, Deskripsi Toko, Password dan konfirmasi password untuk LoginTerdapat beberapa tingkatan pengguna yang memiliki hak akses masing-masing.

Terdapat beberapa tingkatan pengguna yang memiliki hak akses masing-masing, yaitu :

a. Admin

Admin merupakan user tertinggi yang dapat mengakses web dan aplikasi. Bertugas sebagai pengurus bagian registrasi seller baru yang mana apabila pengrajin ingin menjadi seller, maka admin lah yang akan mendaftarkannya. Admin juga dapat menambahkan atau menghapus kategori baru untuk iklan.

b. Seller 
Merupakan jenis akun yang dapat menerbitkan iklan untuk ditampilkan pada aplikasi. Akun ini juga dapat mengakses web dan aplikasi. Bedanya adalah akun dengan tipe seller tidak dapat menambah atau mendaftarkan seller baru.

c. Customer

Merupakan jenis akun yang hanya dapat mengakses aplikasi. Jenis akun ini adalah akun yang registrasi melalui aplikasi. Akun ini tidak dapat menerbitkan iklan

\subsection{Pelatihan dan pendampingan Aplikasi Android dan Website}

Dari analisis lapangan, strategi pemasaran yang sudah ada selama ini sudah berlangsung secara turun temurun dari tahun ke tahun. Program aplikasi yang dibuat peneliti dapat dipakai sebagai strategi penetrasi pasar dan perluasan pasar. Artinya selain melayani pasar yang sudah ada, dengan aplikasi android yang dapat diakses melalui Play Store di smartphone akan menambah pemasaran secara langsung. Hal ini perlu karena pasar gamelan tidak hanya bersifat lokal saja, tetapi juga internasional. Siapapun dapat membeli produk gamelan secara langsung melalui Aplikasi Android Gamelan Wirun.
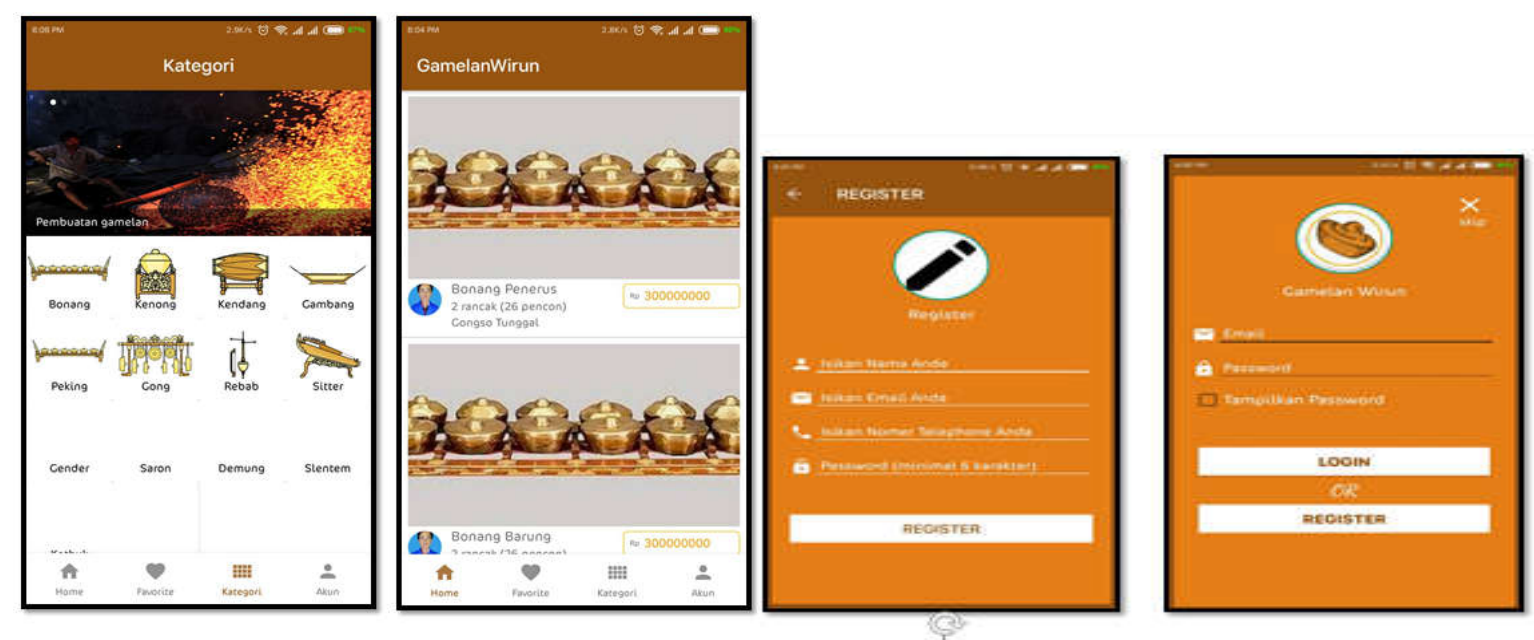

Gambar 1 Program Aplikasi Gamelan Wirun

Pada tahap ini, tim pengusul memberikan pelatihan berupa materi tentang penggunaan menu

1. Admin

2. Seller

\section{HASIL DAN PEMBAHASAN}

\subsection{Admin}

Untuk masuk ke halaman admin, silakan akses ke alamat www.gamelan-wirun.com yang mana terlebih dahulu akan diminta untuk login. Silakan masukkan email dan password yang telah terdaftar sebagai admin. 

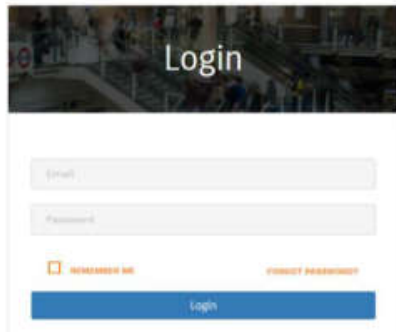

Gambar 2 Login Admin

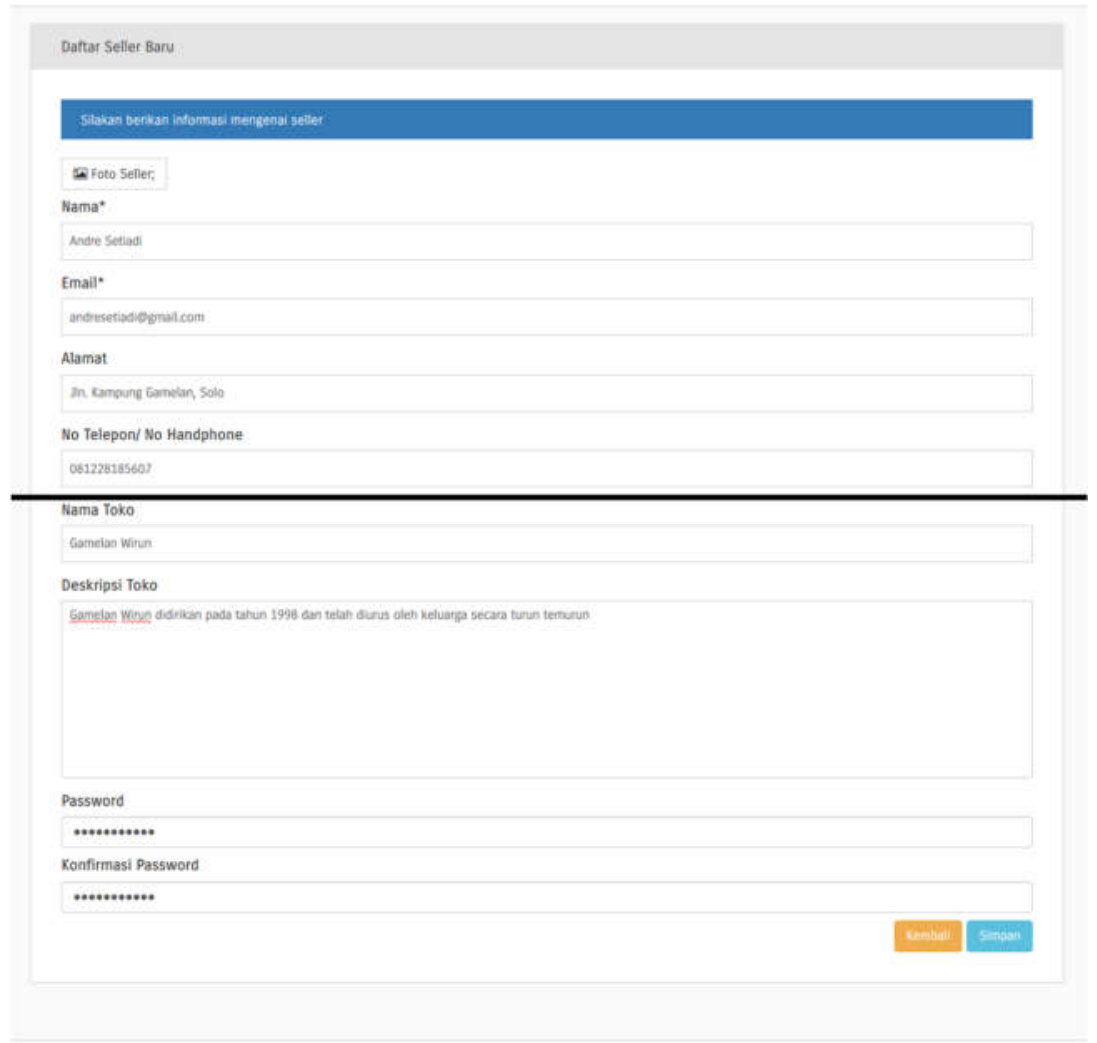

Gambar 3 Pengisian Formulir Seller

\subsection{Seller}

Sama seperti halaman admin, untuk mengakses halaman seller harus login terlebih dahulu dengan akun yang telah didaftarkan. Setelah login berhasil maka akan masuk ke halaman dashboard yang mana terdapat beberapa menu yang berbeda dari akun admin yakni menu :

- Menu Iklan

- Menu Form 
Menu Iklan merupakan menu untuk masuk ke halaman daftar iklan yang telah diposting oleh seller, yang mana terdapat informasi singkat mengenai iklan serta tombol detail (kaca pembesar) dan edit (pensil) yang berfungsi untuk melihat detail iklan dan mengedit informasi iklan. Adapun bentuknya adalah sebagai berikut :

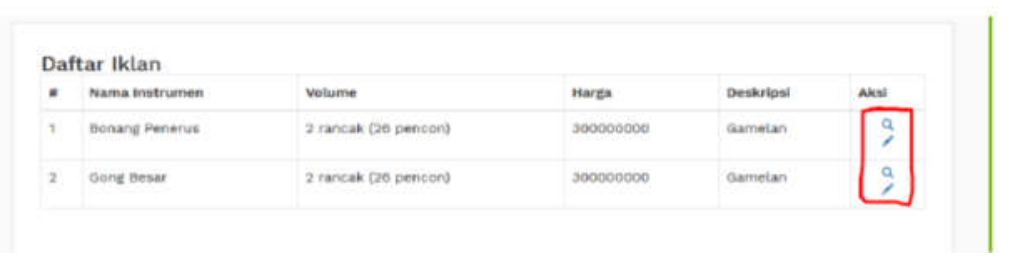

Gambar 4 Halaman Daftar Iklan

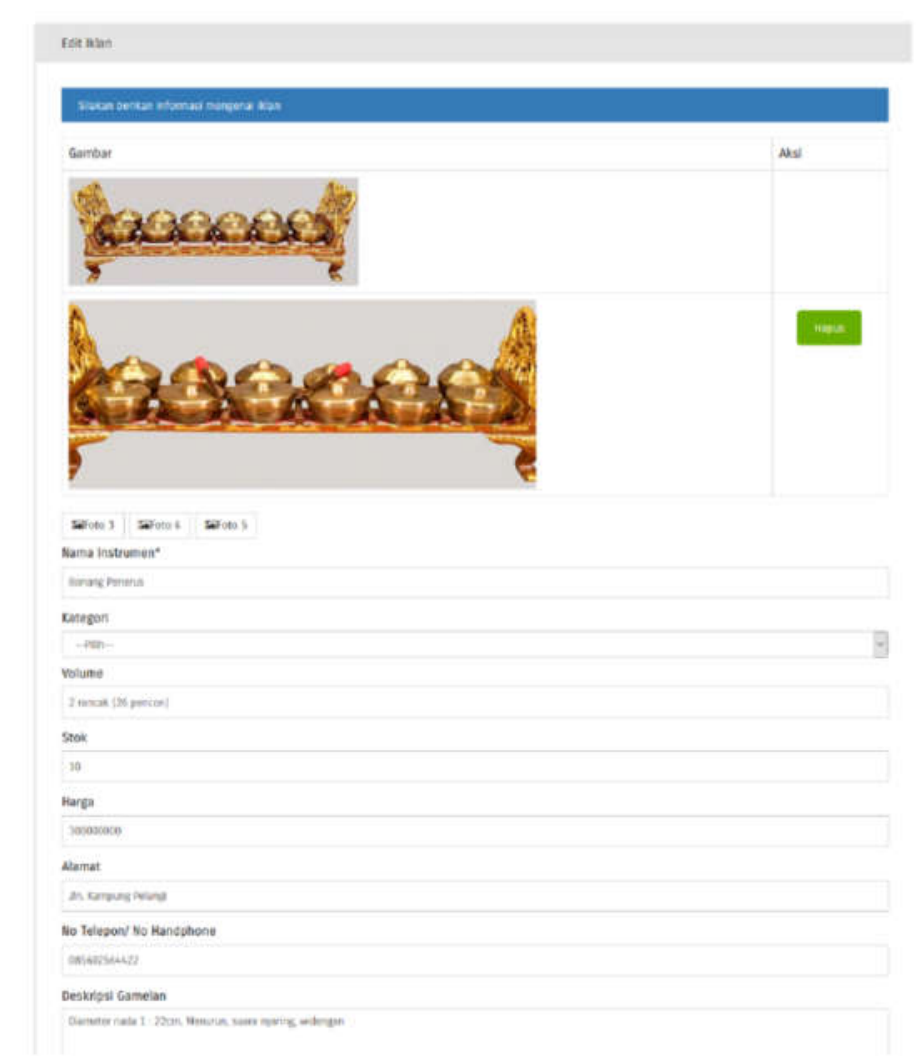

Gambar 5 Halaman Edit Iklan

\section{KESIMPULAN}

Pelaku industri kreatif gamelan sangat terbantu dengan aplikasi android Galeman Wirun. Sebelumnya para pengrajin gemelan di Wirun belum banyak memanfaatkan teknologi informasi. Dengan pendampingan dan pelatihan membuat pengrajin gamelan lebih aware terhadap pemanfaatan teknologi informasi untuk pengembangan usaha.

Pembuatan aplikasi android Gamelan Wirun dibuat untuk strategi penetrasi pasar dan perluasan pasar, yaitu meningkatkan penjualan gamelan melalui teknologi. Aplikasi ini dapat diakses melalui play store android di smartphone. Dengan demikian pasar menjadi langsung, artinya pembeli gemelan 
dimanapun baik lokal, nasional maupun di seluruh dunia dapat langsung berinteraksi melalui program Aplikasi Gamelan Wirun.

\section{DAFTAR PUSTAKA}

[1] www.kemenpar.go.id

[2] http://www.kapanlagi.com

[3]Chikweche, T. and Fletcher, R. (2017), "Entrepreneurship and ethics under extreme conditions of poverty: "Exploring the realities"", Society and Business Review, Vol. 12 No. 1, pp. 419. https://doi.org/10.1108/SBR-11-2015-0065

[4]Haugh, H.M. and Pardy, W. (1999), "Community entrepreneurship in north east Scotland", International Journal of Entrepreneurial Behavior \& Research, Vol. 5 No. 4, pp. 163172. https://doi.org/10.1108/13552559910293119

[5] Merlo, O \& Auh, S.(2009). The effect of entrepreneurial orientation, market orientation andmarketing subunit influence on firm performance. Marketing Letters. 20. 295-311.

[6] Pramudi, Tyas., Model Pembelajaran Multimedia Seni Gamelan Jawa, Riptek, Vol. 4, No. 1, 2010

[7] Pramudi, Tyas., Budiman, Fikri., Sunardi, Desain Virtual Gamelan Jawa sebagai Medi Pembelajaran, Seminar Nasional Aplikasi Teknologi Informasi, 2010. 